\title{
Service Quality and Customer Satisfaction - With Special focus on the Online Cab Industry in India
}

\author{
Kiran Sharma ${ }^{1} \&$ Saptarshi Das ${ }^{1}$ \\ ${ }^{1}$ Marketing, K. J. Somaiya Institute of Management Studies and Research, Mumbai, India \\ Correspondence: Kiran Sharma, Marketing, K. J. Somaiya Institute of Management Studies and Research, \\ Mumbai, Mumbai, India. Tel: 91-226-728-3096. E-mail: kiransharma@somaiya.edu
}

Received: May 5, 2017

Accepted: June 2, 2017

Online Published: June 7, 2017

doi:10.5539/ijbm.v12n7p192

URL: https://doi.org/10.5539/ijbm.v12n7p192

\begin{abstract}
The construct of service quality as enunciated by Parasuraman, A., Zeithaml, V. A., \& Berry, L. L (1985) has been widely studied across various industries. In the recent years, India has witnessed a sudden growth in travel with the advent of the radio cabs service providers. While service quality has been studied as a construct in a multitude of services very minimal research has happened yet on the radio cabs, which makes this a unique study of its kind. The study was undertaken on customers of various radio cabs in India to assess the aspects that they were looking foremost while making use of the radio cab services in India. From a pragmatic viewpoint it may be construed that by understanding influences of various variables on customer satisfaction, marketers are likely to envisage and plan the actions in leveraging the services. The objective in the present study is to identify whether the dimensions of service quality particularly influences a customers' satisfaction.
\end{abstract}

Keywords: service quality, services, customer satisfaction, radio cabs in India

\section{Introduction}

Over the past few years, the radio taxi concept has made city travel simple, secure and convenient in India, especially in the Tier-1 and even in a few of the Tier- 2 cities. Now, a sudden ride to the airport or the railway station or a party is no longer a difficult and a cumbersome situation. A radio-cab booking is just a matter of pressing a few buttons on one's Smartphone to book a cab that takes one to his/her desired destination hassle-free.

So are radio cabs or an on-demand taxi haling service the next big thing in India's Internet marketplace after online retailers Flipkart and Snapdeal? Investors are betting that it could well be. As reported in LiveMint, Friday March $20^{\text {th }} 2015$, companies such as Ola, Taxi For Sure, Uber and Meru are experiencing a boom in demand for their cab services in a country where the transport infrastructure is still creaky and safe public and private commuting options are few. A shift in consumer habits towards convenience and on-demand services, and, most crucially, low prices, have fuelled the boom.

Ola and Uber, in particular, have grown explosively over the past year. Aimed at solving the intra-city commuting problems of customers, these radio cab services have perfectly capitalized on the growing engagement with the Smartphone and the need for convenience to commute to different destinations at different times of the day, by offering car rides at prices lower than the fares charged by auto rickshaws. How long can such prices be sustained for is anyone's guess, but for now these companies continue to spend massive amounts of capital on marketing, discounts, recruiting thousands of new drivers and expanding into new markets.

Earlier, cabs were mostly used for airport rides. That has changed now because of the unrivalled ease of access offered by mobile apps. All the large companies, including Ola and Meru, get a majority of their business from mobile apps, while Uber is entirely app-based.

Two other models exist: cabs for long-duration travel and rentals.

Savaari, backed by Inventus Capital Partners and Intel Capital, offers cabs for long-duration travel, avoiding direct competition with the likes of Ola and Meru. The firm does about 7,000 trips in a day, with an average ticket size of Rs.3,500-4,000, co-founder Gaurav Aggarwal said. 
ZoomCar India and Carzonrent follow variations of the rental model and both have received funding from investors.

But in spite of the arrival of a number of players in the intra-city as well as inter-city commutation sector, the market still remains largely unorganized with a lack of penetration of these radio-cab companies into the tier-2 and tier-3 cities of India. With India's sizeable and ever-growing middle and upper middle-class segment, especially in the tier- 2 and tier-3 cities, there is an enormous market potential for these companies to make their mark and increase their customer base.

With the vision for the future, all these companies have received handsome funding from investors looking forward to being a part of a bright growth story of the radio cab service industry in India.

\begin{tabular}{|c|c|c|c|}
\hline NAME & FOUNDED IN & FOUNDERS & INVESTORS \\
\hline Ola & 2011 & Bhavish Aggarwal and Ankit Bhati & $\begin{array}{l}\text { SoftBank, Tiger Global, Matrix Partners, } \\
\text { Sequoia Capital }\end{array}$ \\
\hline TaxiforSure & 2011 & Aprameya Radhakristna and Raghunandan G. & Accel Partners, Qualcomm, Helion \\
\hline Savaari & 2006 & $\begin{array}{l}\text { Gaurav Aggarwal, Monit Khanna, Manik Shah } \\
\text { and Rahul Khanna }\end{array}$ & Inventus Capital, Intel Capital \\
\hline Meru & 2006 & Neeraj Gupta & India Value Fund \\
\hline Mega Cabs & 2001 & Kunal Lalani & - \\
\hline Uber & $\begin{array}{l}\text { 2009, entered } \\
\text { India in } 2013\end{array}$ & Travis Kalanick and Garrett Camp & $\begin{array}{l}\text { Goldman Sachs, Menlo Ventures, Bezcs } \\
\text { Expeditions }\end{array}$ \\
\hline Zoom Car & 2013 & David Back, Greg Moran & Sequoia Capital \\
\hline
\end{tabular}

But before devising an elaborate market penetration strategy, the radio-cab companies need to carefully evaluate the target group of customers and their pain-points which these companies would look to alleviate. The services industry in India is intricately linked to customer satisfaction. Thus, understanding the various factors impacting customer satisfaction would be the first step towards identifying a gap in the existing market and subsequently devising a strategy to align the existing business model of these companies with the demand for improved services.

\section{Literature Review}

Over recent years, the service sector has recorded impressive growth, to the extent that its contributions to global gross domestic product (GDP) now exceed those from other economic sectors (Ostrom et al. 2010). Parallel to this growth, there is an ongoing shift from a production-oriented perspective, focused on producing goods or on providing services, to a perspective in which the customer is seen as central. Many companies are shifting their product-oriented business models to a service-oriented direction.

According to Calabrese A. and Spandoni A. (2013), service productivity and perceived service quality are both critical success factors for companies (Marinova, Ye, and Singh 2008). Thus in its operations, a service provider must achieve both the highest perceived service quality (HPSQ) and Technical Efficiency (TE) (Grönroos and Ojasalo 2004). A service provider characterised by both the HPSQ and TE is then an efficient service provider (ESP).However, for an ESP, an increase in productivity also causes a reduction in the quality perceived by customers.

According to Khurana S. (2014), in today's intense competitive business world, the customer is educated and smart and commands satisfaction in all services. Banking is one of the numerous services in which customer satisfaction has an ever growing importance in the analogous research areas. This is basically because the banking sector is becoming more and more aggressive in its marketing approach. Retail banks are pursuing this approach, in part, because of the complexity in differentiating based on the service offering.

Wireless services are another sector where the customer is quite educated with a lot of freely available information from various sources. The different companies in this industry looking to engage on a greater level with customers to gain significant increase in market share are looking into various dimensions which may impact customer satisfaction. Various studies have shown that service quality relative to value is of paramount importance in creating customer satisfaction in developed markets; in emerging markets, satisfaction does not play a very significant role in inducing customer loyalty.

In the field of hospitality services, which is a very low-differentiated category, it is imperative to focus on and improve the quality of the customer touch-points - the moments of truth, where the customer comes in direct contact or interaction with the service provider, which can leave a lasting impression, positive or negative, in the 
minds of the customer. According to Bilgili B., Candan B. and Bilgili S. (2014), recent studies have determined that relational benefit is an influential factor on quality, image and customer loyalty especially in the hospitality industry. Relational benefit consists of three dimensions - social benefit, trust and special care. All the three dimensions need to be leveraged upon to create an irresistible value proposition for the target customer.

In the context of services offered by a service provider to the customer, there are various touch-points or aspects that determine the quality of the service rendered. These touch-points or factors contribute to the service quality - exceeding, just satisfying or not living up to the expectations of the customers. Each of these parameters may contribute in varying ways and differing degrees to the enhancement or degradation of service quality ultimately resulting in customer satisfaction. This research exercise will seek to evaluate the various parameters of the service quality model for online taxi services like timeliness, price, bill given by the driver at the end of the ride, cleanliness of the driver, courteous behaviour by the driver and other persons that the customer might be in contact with and the presence of a GPS tracker within the cab. This will help the online cab companies to identify their target group of customers and create a market penetration cum marketing strategy before venturing into new markets or cities in India.

In a complex service production/delivery process, many events can potentially trigger service failures (Smith, Bolton, and Wagner 1999). Similarly, many opportunities exist to create delights for customers (Rust and Oliver 2000). At times, customers may even experience a mixture of service failures and delights during a prolonged service process. Therefore, companies need to make intelligent resource allocation decisions on various forms of failure prevention, delight creation, or a mixture of both to maximize return on service quality (Rust, Zahorik, and Keiningham 1995).

The SERVQUAL Model is a service quality framework developed in the 1980s by Zeithaml, Parasuraman and Berry, aimed at measuring the scale of quality in the various services in the service sector. SERVQUAL was originally measured on ten aspects of service quality - reliability, responsiveness, access, competence, communication, courtesy, security, credibility, understanding the customer, and tangibles, to measure the gap between customer expectations and experience. In 1988, the ten components were collapsed into five dimensions (RATER). Reliability, responsiveness and tangibles remained distinct, but the other seven components were merged into two broad dimensions - assurance and empathy.

According to the SERVQUAL model developed by Parasuraman, Zeithaml and Berry, to measure the quality of service, consumers compare the service they actually received with that of the expected service quality. Service quality calculated mathematically: P - E (where ' $\mathrm{P}$ ' indicates consumer's perceived level of service and ' $E$ ' stands for consumer's expected level of service). In the given formula above, a negative result bears the fact that service quality was below expectations; a zero indicates that customer expectations were met; whereas a positive quantity states that expectations were exceeded.

\subsection{Components of Service Quality}

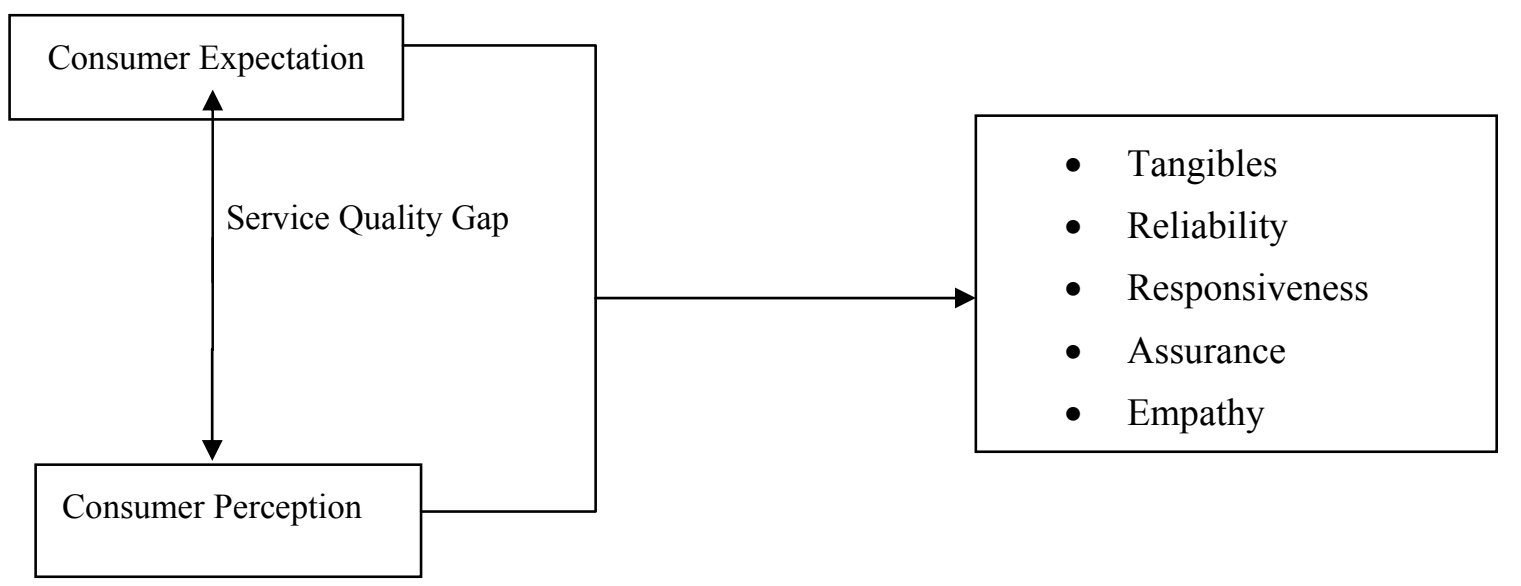

\subsection{SERVQUAL Dimensions and Statements}

The following table defines the five parameters of the SERVQUAL model and tries to align them with the various factors affecting customer satisfaction in online cab services. 


\begin{tabular}{|c|c|c|}
\hline 1. & $\begin{array}{l}\text { Tangibles } \\
\text { Appearance of physical facilities, equipment, personnel and } \\
\text { printed and visual materials }\end{array}$ & $\begin{array}{l}\text { - The cab should have a GPS System. } \\
\text { - The colour, exterior and interior facilities should } \\
\text { provide comfort to the passenger and should be visually } \\
\text { appealing. } \\
\text { - The cab driver should be neat in appearance and } \\
\text { courteous. } \\
\text { - The cab service should not be overpriced. } \\
\text { - A bill should be handed to the passenger at the end } \\
\text { of the journey. }\end{array}$ \\
\hline 2. & $\begin{array}{l}\text { Reliability } \\
\text { Ability to perform the promised service dependably and } \\
\text { accurately }\end{array}$ & $\begin{array}{l}\text { - The cab service should make sure that the passenger } \\
\text { reaches his destination in the stipulated period of time. } \\
\text { - When a customer has a problem, good cab services } \\
\text { show a genuine interest in solving it. } \\
\text { - } \quad \text { Good cab services will be dependable. } \\
\text { - There should be no security-related issues for female } \\
\text { passengers. }\end{array}$ \\
\hline 3. & $\begin{array}{l}\text { Responsiveness } \\
\text { The willingness to help customers and provide prompt service }\end{array}$ & $\begin{array}{l}\text { - Good cab services make sure that their cab arrives } \\
\text { for pickup of the passenger at the desired location without } \\
\text { delay. } \\
\text { - Good cab services are always willing to listen to } \\
\text { customer complaints and improve various facets of their } \\
\text { services, if any. }\end{array}$ \\
\hline 4. & $\begin{array}{l}\text { Assurance } \\
\text { The knowledge and courtesy of employees and their ability to } \\
\text { inspire trust and confidence }\end{array}$ & $\begin{array}{l}\text { - The behaviour of the cab-driver will please the } \\
\text { passenger. } \\
\text { - The customers of the cab service, male or female, } \\
\text { will feel safe while travelling in the cab. } \\
\text { - The driver will know alternative routes to reach the } \\
\text { destination in case of any impediment to the usual route } \\
\text { like traffic congestions or blockades. }\end{array}$ \\
\hline 5. & $\begin{array}{l}\text { Empathy } \\
\text { Trustworthiness, believability, honesty, caring, individualized } \\
\text { attention provided to customers. }\end{array}$ & $\begin{array}{l}\text { - Cab services should provide } 24 * 7 \text { services to the } \\
\text { customer. } \\
\text { - Good cab services will always have the passenger's } \\
\text { best interests at heart. } \\
\text { - Good cab services will always keep the customer } \\
\text { informed of any delay or inability to deliver the services. }\end{array}$ \\
\hline
\end{tabular}

\subsection{Service Quality Gap Model}

According to Parasuraman, service quality is the difference between expectation and performance along the quality dimensions. The following table represents the service quality model developed on the basis of gap analysis:

\footnotetext{
Gap Difference between consumer's expectations and management perception of those expectations i.e not having enough information 1 about consumer expectations.

Gap2 Difference between management's perception of consumer expectations and service quality specifications i.e improper service quality standards.

Gap Difference between service quality specifications and service actually delivered i.e the service quality gap.

3

Gap Difference between service delivery and communications to consumers about service delivery i.e the match between actual delivery

$4 \quad$ and promises made.

Gap Difference between consumers' expectations and the perceived service. This depends on the size and direction of the four earlier 5 mentioned gaps from the marketer's side.
} 


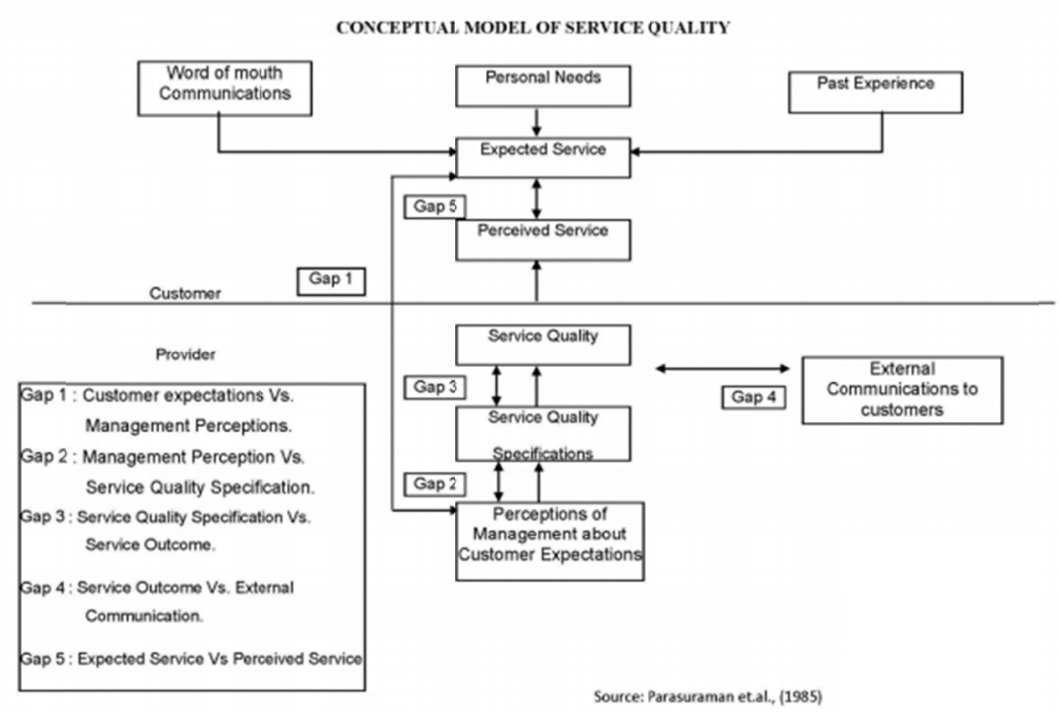

According to this model, service quality is a function of perceptions and expectations and can be modelled as:

$$
\mathrm{SQ}=\sum_{j=1}^{k}\left(P_{i j}-E_{i j}\right)
$$

Where

$\mathrm{SQ}=$ Overall service quality

$\mathrm{k}=$ Number of attributes

$\mathrm{P}_{\mathrm{ij}}=$ Performance of stimulus $\mathrm{i}$ with respect to attribute $\mathrm{j}$

$\mathrm{E}_{\mathrm{ij}}=$ Service quality expectation for attribute $\mathrm{j}$, that is the usual norm for stimulus $\mathrm{i}$

Empirical research by PIMS (Profit Impact of Marketing Strategies) shows a positive relationship between service quality and organizational performance. Using a large database with thousands of strategic business units, the research clearly states that the success of an organization in the marketplace depends on the customer-perceived quality of its products or services with respect to that of the competitors. According to Reichheld and Sasser (1990), retaining customers through service quality helps in shoring up profits as a result of increased purchases and referrals, price premiums and reduced operating costs.

Unfortunately, in today's scenario, for most companies, the focus is entirely on short term financial performance, productivity and efficiency, rather than on long-term customer satisfaction and value. This myopic vision acts as an impediment for companies in creating a long-term strategy to retain and increase market share and more importantly, increase the size of the market by acquiring newer customers. To demonstrate fully the impact of service quality and customer satisfaction to organizational performance, other measuring parameters must be added to the corporate report card. A healthy balance between short-term financial and operational performance and a long-term strategic vision to deliver greater value to the customers is essential for an organization to create a sustainable competitive advantage in the business landscape.

This research tries to evaluate the effectiveness of some of the existing business models and strategies of the existing online cab service providers in India. The research will study the contribution of the various parameters in the cab services in providing customer satisfaction. It will also attempt to suggest some other parameters that the companies could look into to provide an improved value proposition to customers. This will create a strategic vision for the existing players to penetrate deeper into the markets they already operate in and also expand their services to newer markets, using the competitive advantage gained through efficient resource allocation and innovation in the services offered.

\subsection{Objective}

The Objectives of this research are primarily three fold: 
Firstly to assess customer opinion about Online Cab Services on the five parameters of the ServQual model Tangibles, Reliability, Responsiveness, Assurance, Empathy. Secondly, to check the reliability of the data derived from the responses on the five parameters in determining overall Customer Satisfaction from the Online $\mathrm{Cab}$ Services. Finally to assess the impact of each of the five parameters on the Overall Customer Satisfaction derived from the Online Cab Services.

\section{Research Methodology}

The study is exploratory in nature with a convenience sample of 84 from Mumbai. A total of 135 questionnaires were distributed. After scanning the returned questionnaires and disregarding those giving incomplete responses on one or more of the variables 84 were complete and usable questionnaires remained (representing a response rate of $63 \%$ ). The sample comprised of 55 males and 29 females. Data collection was carried out using an adaptation of the Structured Questionnaire developed by Parasuraman, A., Zeithaml, V. A., \& Berry, L. L. (1985) The questionnaire was adapted to suit the needs of the current study. The data collected from the respondents was analysed using SPSS software and both univariate and multivariate analyses were performed. The conclusions were drawn based on the outcomes of the analyses.

\section{Results and Analysis}

The means and standard deviations for the various dimensions of service quality and customer satisfaction are presented in Table 1. They have been fund to be comparable to sample means as reported in previous researches. Following the suggestions by Gregory 2000, Nunally (1979) a Cronbach's alpha of 0.70 was set as the criterion for minimum internal consistency. The scale revealed an alpha coefficient of $0.73(\mathrm{~N}=84)$ indicating good reliability (Gregory, 2000). The data was tested for normality and other assumptions of multivariate data analysis and no deviations were found (Tabachnick \& Fidell, (2001).

The Cronback Alpha Value derived from the Reliability test is .728, suggesting that the items have a relatively high internal consistency.

Table 1. Item-Total Statistics

\begin{tabular}{lllll}
\hline & \multicolumn{2}{l}{$\begin{array}{l}\text { Scale Mean } \\
\text { Deleted }\end{array}$} & $\begin{array}{c}\text { Item Scale Variance if Item Corrected } \\
\text { Deleted }\end{array}$ & $\begin{array}{l}\text { Item-Total Cronbach's Alpha if } \\
\text { Correlation }\end{array}$ \\
\hline Tangibles & 17.8542 & 6.089 & .494 & .681 \\
Reliablity & 17.7569 & 6.395 & .411 & .705 \\
Responsiveness & 17.8194 & 6.196 & .570 & .665 \\
Assurance & 17.4058 & 7.170 & .087 & .814 \\
Empathy & 17.8819 & 5.370 & .629 & .635 \\
Overall Satisfaction & 17.6558 & 5.562 & .768 & .607 \\
\hline
\end{tabular}

From the above table, we can see that Cronback's Alpha if Item Deleted value is higher than the original Cronback's Alpha value of .728 only for Assurance, which is .814. This tells us that, the Reliability of the test would increase if we remove the parameter of Assurance.

In the above table, the Pearson Correlation value for dependent variable Overall Satisfaction is greater than 0.5 for the independent variables Tangibles, Responsiveness and Empathy. This shows that there is a strong correlation between them. On the other hand, the Pearson Correlation values for Reliability and Assurance being less than 0.5 shows that they are weakly related with Overall Satisfaction.

Again, since the level of Significance is less than 0.05 for all the independent variables, it shows that some level of correlation does exist between the Dependent variable and each independent variable. 
Table 2. Inter-correlations among Dimensions of Service Quality and Overall Customer Satisfaction

\begin{tabular}{|c|c|c|c|c|c|c|c|c|}
\hline & Mean & Standard Deviation (S.D.) & 1 & 2 & 3 & 4 & 5 & 6 \\
\hline Overall Customer Satisfaction & 3.619 & 0.657 & & $0.595^{* *}$ & $0.455^{* *}$ & $0.622 * *$ & $0.182 * *$ & $0.627^{* *}$ \\
\hline Tangibles & 3.421 & 0.723 & & & $0.228^{* *}$ & $0.34 * *$ & $0.043 * *$ & $0.512 * *$ \\
\hline Reliability & 3.518 & 0.709 & & & & $0.407 * *$ & -0.054 & $0.456^{* *}$ \\
\hline Responsiveness & 3.455 & 0.628 & & & & & $0.108 * *$ & $0.469 * *$ \\
\hline Assurance & 3.869 & 0.889 & & & & & & $0.064 * *$ \\
\hline Empathy & 3.393 & 0.807 & & & & & & \\
\hline Note : $* * \mathbf{p}<0.01$ & & & & & & & & . \\
\hline
\end{tabular}

Regression Analysis: The independent variables Tangibles, Responsiveness and Empathy were considered in the Regression Model, since they have a Pearson Coefficient value of greater than 0.5 with the dependent variable, Overall customer Satisfaction. Since the other two independent variables, Reliability and Assurance, have Pearson Coefficient values less than 0.5, they were eliminated from the Regression Model.

Table 3. Regression Model

\begin{tabular}{|c|c|c|c|c|c|c|c|c|c|c|}
\hline \multirow[b]{2}{*}{ Model } & \multirow[b]{2}{*}{$\mathbf{R}$} & \multirow[b]{2}{*}{ R Square } & \multicolumn{7}{|c|}{ Change Statistics } & \multirow[b]{2}{*}{$\begin{array}{l}\text { F Durbin-W } \\
\text { atson }\end{array}$} \\
\hline & & & $\begin{array}{l}\text { Adjusted } \\
\text { Square }\end{array}$ & $\begin{array}{l}\text { R Std. Error of the } R \\
\text { Estimate }\end{array}$ & $\begin{array}{l}\text { R Square } \\
\text { Change }\end{array}$ & F Change & df1 & df2 & $\begin{array}{l}\text { Sig. } \\
\text { Change }\end{array}$ & \\
\hline 1 & $.627^{\mathrm{a}}$ & .393 & .385 & .51492 & 393 & 53.060 & 1 & 82 & .000 & \\
\hline 2 & $.729^{\mathrm{b}}$ & .531 & .520 & .45522 & .138 & 23.918 & 1 & 81 & .000 & \\
\hline 3 & $.778^{\mathrm{c}}$ & .606 & .591 & .42015 & .074 & 15.086 & 1 & 80 & .000 & 2.237 \\
\hline \multicolumn{11}{|c|}{ a. Predictors: (Constant), Empathy } \\
\hline \multicolumn{11}{|c|}{ b. Predictors: (Constant), Empathy, Responsiveness } \\
\hline \multicolumn{11}{|c|}{ c. Predictors: (Constant), Empathy, Responsiveness, Tangibles } \\
\hline \multicolumn{11}{|c|}{ d. Dependent Variable: Overall customer satisfaction } \\
\hline
\end{tabular}

The above table indicates that the Durbin-Watson value is 2.237 , that is, close to 2 . This shows that there is no autocorrelation between the variables, that is, they independently affect the dependent variable. Again, the value of R Square increases from Model 1 to Model 3, showing that as we take more number of variables, the reliability of the Regression model increases. The model has been found to be statistically significant.

Table 4. Regression coefficients

\begin{tabular}{|c|c|c|c|c|c|c|c|c|}
\hline & & \multicolumn{2}{|c|}{$\begin{array}{l}\text { Unstandardized } \\
\text { Coefficients }\end{array}$} & \multicolumn{3}{|c|}{$\begin{array}{l}\text { Standardized } \\
\text { Coefficients }\end{array}$} & \multicolumn{2}{|c|}{ Collinearity Statistic } \\
\hline \multicolumn{2}{|c|}{ Model } & B & Std. Error & Beta & $\mathbf{T}$ & Sig. & Tolerance & VIF \\
\hline \multirow[t]{2}{*}{1} & (Constant) & 1.888 & .244 & & 7.730 & .000 & & \\
\hline & Empathy & .510 & .070 & .627 & 7.284 & .000 & 1.000 & 1.000 \\
\hline \multirow[t]{3}{*}{2} & (Constant) & .912 & .294 & & 3.101 & .003 & & \\
\hline & Empathy & .350 & .070 & .429 & 4.986 & .000 & .780 & 1.282 \\
\hline & Responsiveness & .440 & .090 & .421 & 4.891 & .000 & .780 & 1.282 \\
\hline \multirow[t]{4}{*}{3} & (Constant) & .465 & .295 & & 1.576 & .119 & & \\
\hline & Empathy & .232 & .071 & .285 & 3.243 & .002 & .640 & 1.563 \\
\hline & Responsiveness & .397 & .084 & .380 & 4.739 & .000 & .767 & 1.304 \\
\hline & Tangibles & .291 & .075 & .320 & 3.884 & .000 & .725 & 1.379 \\
\hline
\end{tabular}

a. Dependent Variable: Overall Satisfaction 
From the above table, we can get the Regression Equation for Model 3. This model includes the three parameters, Empathy, Responsiveness and Tangibles that contribute to the dependent variable, Overall Customer Satisfaction.

\section{Regression Equation: $\mathbf{Y}=\mathrm{A}+\mathrm{BX}_{1}+\mathrm{CX}_{2}+\mathrm{DX}_{3}$}

In the above scenario,

$$
Y=.465+.285 X_{1}+.380 X_{2}+.320 X_{3}
$$

Where

$\mathrm{Y}$ - Overall Customer Satisfaction

$\mathrm{X}_{1}$ - Empathy

$\mathrm{X}_{2}-$ Responsiveness

$\mathrm{X}_{3}$ - Tangibles

The other two parameters of the ServQual Model, Reliability and Assurance, were excluded from the Regression Model, since their Pearson Coefficient values, came to be less than 0.5.

\section{Conclusions}

The Tangibles, or the appearance of physical facilities, equipment, personnel and printed and visual materials, play a significant role in Overall Customer Satisfaction derived from the Online Cab Services. To attract customers, the cab companies must have up-to-date equipment, visually appealing physical facilities within the cab and the well-dressed cab drivers.

The Responsiveness or the willingness to help customers and provide prompt service plays a vital role in Overall Customer Satisfaction. Hence, the cab services must maintain punctuality, explicitly reveal all the services provided, provide prompt services and have round-the-clock operating hours.

Thirdly, Empathy, or trustworthiness, believability, honesty, caring, individualized attention provided to customers also plays a critical role in determining Overall Customer Satisfaction. Thus, the cab services and the drivers should be sympathetic and reassuring towards the customer's problems and they should also be courteous, helpful and sensitive to individual customer requirements.

Reliability and Assurance, or the ability to deliver the promised services dependably and accurately, thereby being able to gain the trust and confidence of the customer, are not significant enough in contributing to the Overall Customer Satisfaction.

One of the reasons for the above phenomena may be that the Indian customers aren't yet as comfortable using Online Cab Services like Ola, Uber or Meru as their counterparts in Western developed countries. They still prefer the on-road running taxis to take them to their desired destinations. Secondly, it may be due to the the lack of trust with the billing and payment systems of the Online Cab Services. Being used to the bill generated by local taxis at the end of the journey, getting accustomed to the new bill generation and payment system will take some time for Indian customers. Finally, in India, we face a lot of security concerns especially for women than in Western countries. Hence, women in India are not as comfortable in travelling in taxis alone as in the Western developed nations. Hence, reliability or the trust factor is low in India when compared to other countries.

\section{Limitations and Future Scope of the Study}

The research sample was taken mostly from a particular B-School campus in Mumbai, hence it cannot be used to be generalized for pan India. The answers may include biases of individual respondents to a particular aspect of the services received, thereby decreasing the objectivity of the study. Some of the questions were negatively phrased to check the constancy of the responses; some of these questions may have seemed ambiguous to the respondent.

This study takes into consideration just the surface of the iceberg for the huge potential for Online Cab Services in India. Online Cab Services are becoming increasing popular in India, being from Tier-1 cities and now percolating down to Tier-2 and Tier-3 cities as well. The Online Cab Services provide a cheaper and much convenient mode of transport for passengers looking to travel intra-city or even inter-city.

With many foreign companies like Uber making a foray into the Indian marketplace and Indian companies like OLA and Meru Cabs providing stiff competition, the companies need to establish significant points of differences from their competitors while maintaining the basic points of parity. This will help them gain a sustainable competitive advantage over their rivals and gain an early share of the Indian market. 
The study can be conducted on a much larger scale across various cities in India, Tier-1, Tier-2 and Tier-3, with a greater number of variables, to understand customer sentiment towards these Cab Services and the various drivers towards customer decision-making to avail these services.

A Porter's Five Forces Model can be developed to evaluate the competitive landscape and it can thus be used to devise market-entry or market penetration strategies for companies.

\section{References}

Bilgili, B., Candan, B., \& Bilgili, S. (2014). A Research study on the relationship among relational benefit, perceived quality, image and customer loyalty in different hospitality Businesses. International Journal of Management Cases, 16(3), 20-39.

Calabrese, A., \& Spadoni, A. (2013). Quality versus productivity in service production systems: an organisational analysis. International Journal of Production Research, 51(22), 6594-6606.

Gregory, J. R. (2000). Psychological Testing: History, Principles, and Applications. Toronto: Allyn and Bacon.

Grönroos, C., \& Ojasalo, K. (2004). Service productivity: Towards a conceptualization of the transformation of inputs into economic results in services. Journal of Business Research, 57(4), 414-423. http://doi:10.1016/S0148-2963(02)00275-8

Khurana, S. (2014). The relationship between service quality and customer satisfaction: An empirical study of the Indian banking industry. IUP Journal of Bank Management, 13(4), 51.

Marinova, D., Ye, J., \& Singh, J. (2008). Do frontline mechanisms matter? Impact of quality and productivity orientations on unit revenue, efficiency, and customer satisfaction. Journal of Marketing, 72(2), 28-45.

Nunnally, J. C. (1979). Citation classic-psychometric theory. Current Contents/Social \& Behavioral Sciences, (22), 12.

Ostrom, A. L., Bitner, M. J., Brown, S. W., Burkhard, K. A., Goul, M., Smith-Daniels, V., \& Rabinovich, E. (2010). Moving forward and making a difference: research priorities for the science of service. Journal of Service Research, 13(1), 4-36.

Parasuraman, A., Zeithaml, V. A., \& Berry, L. L. (1985). A conceptual model of service quality and its implications for future research. The Journal of Marketing, 41-50.

Reichheld, F. F., \& Sasser, W. E. (1990). Zero Defections: Quality Comes To Services.

Rust, R. T., \& Oliver, R. L. (2000). Should we delight the customer? Journal of the Academy of Marketing Science, 28(1), 86-94.

Rust, R. T., Zahorik, A. J., \& Keiningham, T. L. (1995). Return on quality (ROQ): Making service quality financially accountable. The Journal of Marketing, 58-70.

Smith, A. K., Bolton, R. N., \& Wagner, J. (1999). A model of customer satisfaction with service encounters involving failure and recovery. Journal of marketing research, 356-372.

Tabachnick, B. G., \& Fidell, L. S. (2001). Multivariate statistics. Needham Heights, MA: Allyn.

\section{Copyrights}

Copyright for this article is retained by the author(s), with first publication rights granted to the journal.

This is an open-access article distributed under the terms and conditions of the Creative Commons Attribution license (http://creativecommons.org/licenses/by/4.0/). 